\title{
Reassessing the relationships between private equity investors and their portfolio companies
}

\author{
Sophie Manigart $\cdot$ Mike Wright
}

Accepted: 11 October 2011/Published online: 30 October 2011

(C) Springer Science+Business Media, LLC. 2011

\begin{abstract}
The scope and purpose of this special issue is to reassess the relationships between private equity (PE) investors and their portfolio companies in the light of the need for venture capital/ private equity (VC/PE) firms to adapt their strategies for value creation in the light of the recent financial crisis. We particularly focus upon VC/PE characteristics that differently contribute to portfolio firm performance. The papers presented in this special issue capture this aim in various ways, reflecting the heterogeneity of $\mathrm{VC} / \mathrm{PE}$ investors and the firms in which they invest. We begin this introductory paper by providing a brief overview of each paper's contribution. We articulate themes for an agenda for future research relating to the heterogeneity of investor types and the contexts in which they invest.
\end{abstract}

S. Manigart $(\square)$

Ghent University and Vlerick Business School,

Ghent, Belgium

e-mail: sophie.manigart@vlerick.com

\section{Wright}

Centre for Management Buy-out Research and Imperial

College Business School, London, UK

e-mail: mike.wright@imperial.ac.uk

M. Wright

Ghent University, Ghent, Belgium
Keywords Private equity - Venture capital . Business angels - Investor heterogeneity - Overview · Future research

JEL Classifications $\quad$ G24 $\cdot$ G32 $\cdot$ L26 $\cdot$ M13

\section{Introduction}

Literature on venture capital (VC) and private equity (PE) depicts a broadly positive view of their activities. Detailed reviews of formal VC are provided by Manigart and Wright (2012), of PE by Wright et al. (2009) and of business angel VCs by Kelly (2007). Most empirical studies covered by these reviews find that the post-investment growth and/or performance of investors' portfolio companies is higher than that of nonventure capital backed companies. This positive effect is attributed to investment managers' selection skills (e.g. Shepherd 1999; Baum and Silverman 2004), their valueadding activities leading to professionalization of portfolio companies (e.g. Sapienza et al. 1996; Baum and Silverman 2004; Colombo and Grilli 2010), the tightened post-investment governance of portfolio companies including monitoring activities (e.g. Filatotchev et al. 2006), the provision of additional financial resources (e.g. Hellmann et al. 2008; Janney and Folta 2006; Vanacker and Manigart 2010) and the transfer of reputation and legitimacy to portfolio companies (e.g. Timmons and Bygrave 1986). 
Current academic evidence has made some recognition of the heterogeneity of VC/PE investors and the differential contribution they make to portfolio companies (Fitza et al. 2009). In light of the worldwide decline in $\mathrm{VC} / \mathrm{PE}$ investment activity due to the financial and economic crisis, VC/PE investors need to re-engineer their business models and differentiate themselves in order to remain attractive partners for entrepreneurial companies. The purpose of this special issue is hence to focus upon VC/PE characteristics and behaviours that differently contribute to portfolio firm performance, as a route for $\mathrm{VC} / \mathrm{PE}$ partners to shape their strategies.

VC/PE investors differ with respect to their resource endowments, including the human capital of their investment managers and partners, their social capital built up through their investment networks and their shareholders, their experience or their legal form. This leads to differences in their investment strategy, e.g., whether they invest in a restricted industry, stage or geographic niche or in a broad range of portfolio companies, and in their investment approach, e.g., how they select and manage their portfolio of companies.

Heterogeneity in VC/PE investor characteristics and investment approach leads to differences in investment outcome. For example, experienced VC/ PE investors with a broad network are especially able to select the best portfolio companies (Gompers et al. 2008) and help them develop, while international investors are relevant for entrepreneurial companies wishing to expand or exit abroad (Mäkelä and Maula 2006, 2008; Zahra et al. 2007; Lockett et al. 2008). However, the extent to which heterogeneity has been recognized in the academic literature is limited. For example, much research focused on independent VC/PE investors and business angels, yet outside the United States many VC/ $\mathrm{PE}$ investors are divisions of financial institutions, corporate VC investors or public sector VC investors (Bottazzi and da Rin 2002). Different types of investors may have different goals, different organizational forms and different abilities, potentially impacting their selection, value adding and exit skills. As VC/PE investors and entrepreneurs need both to survive the crisis and prepare themselves for the post-crisis period, reassessment of which models work best in which context is needed.

\section{Research in this special issue}

Following a general call for submissions, an initial selection of papers was presented at a workshop held at the Vlerick School of Management, Ghent, Belgium. Papers were reviewed according to standard SBE procedures and Table 1 summarizes the papers in the special issue that successfully negotiated this process. Each paper investigates a specific aspect of investor heterogeneity. The majority of the papers focus on early stage VC investors, with one paper addressing the MBO context and two papers incorporating different categories of VC/PE investors: early stage VC investors, later stage $\mathrm{VC}$ investors or business angels. Interestingly, many papers in this special issue use novel databases, often drawing upon hand-collected samples and data. This allows for more refined insights compared to studies relying solely on commercial databases, which, while broad in their coverage of the $\mathrm{VC} / \mathrm{PE}$ industry, lack fine-grained data on $\mathrm{VC} / \mathrm{PE}$ investors and their portfolio companies.

In the VC context, Walz and Hirsch (2012) and Knockaert and Vanacker (2012) investigate investor heterogeneity in VC investors' selection behaviour and suggest that differences in investment approach are associated with differences in the post-investment management process. Walz and Hirsch show that, compared to bank-related and public VC investors, independent $\mathrm{VC}$ investors negotiate contracts that create more possibilities for active intervention postinvestment. This is consistent with the view that independent VC investors are, in general, more handson compared to other types of investors. Knockaert and Vanacker show that independent VCs investing in early stage technology focus more on entrepreneurial team characteristics or financial criteria during selection, are less involved in value adding activities compared to their peers, and focus more on technological criteria during selection.

Bertoni and colleagues (2012a, b) push the differential impact of independent and captive investors further. Short-term sales growth is higher for companies financed by independent VC firms than for companies financed by corporate VC firms, but not short-term employee growth. Long-term growth in sales and employees is the same for both groups. They interpret this as further evidence of grandstanding behaviour by independent VC investors, who are under continuous pressure to raise new funds (Gompers 1996). 


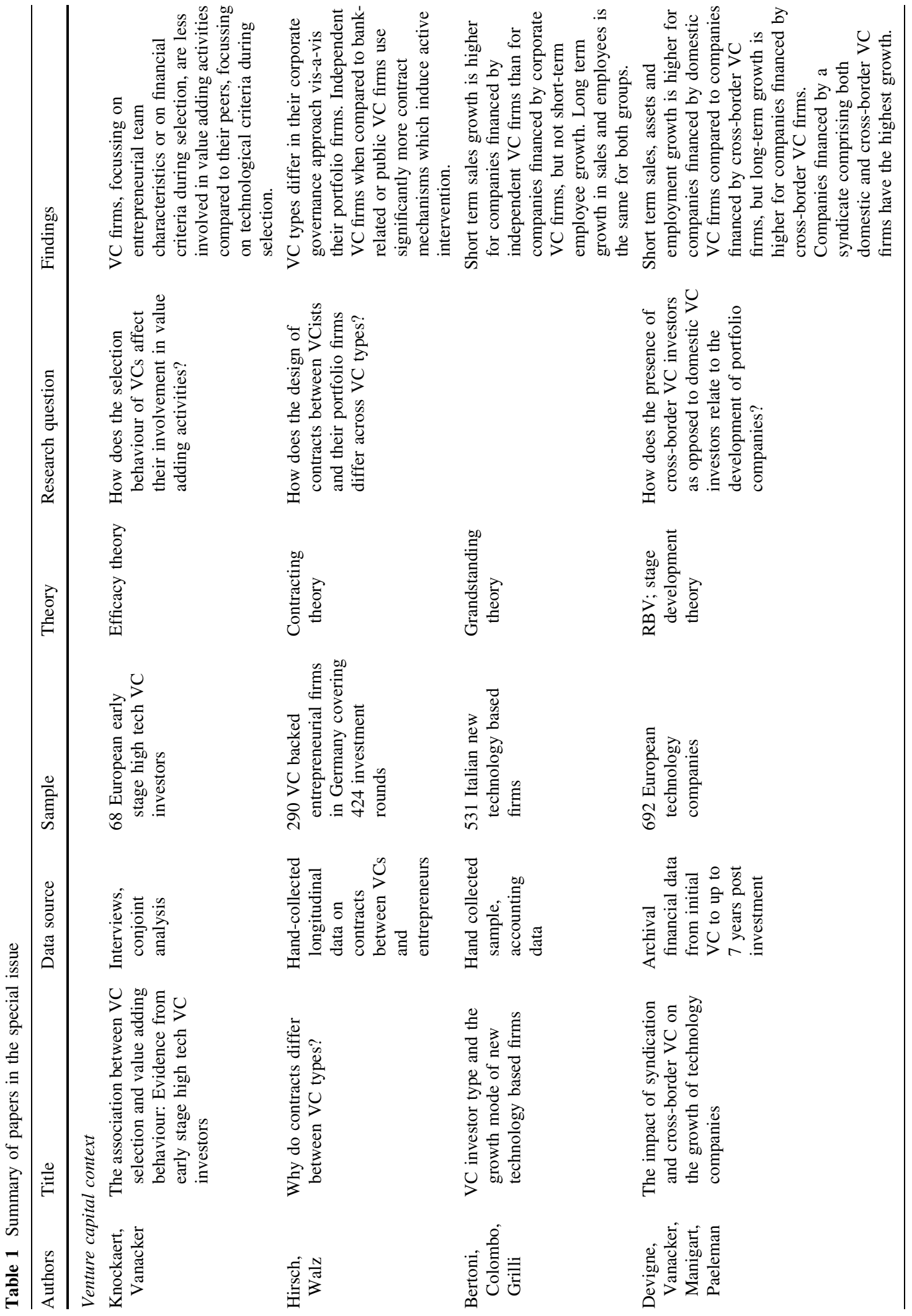




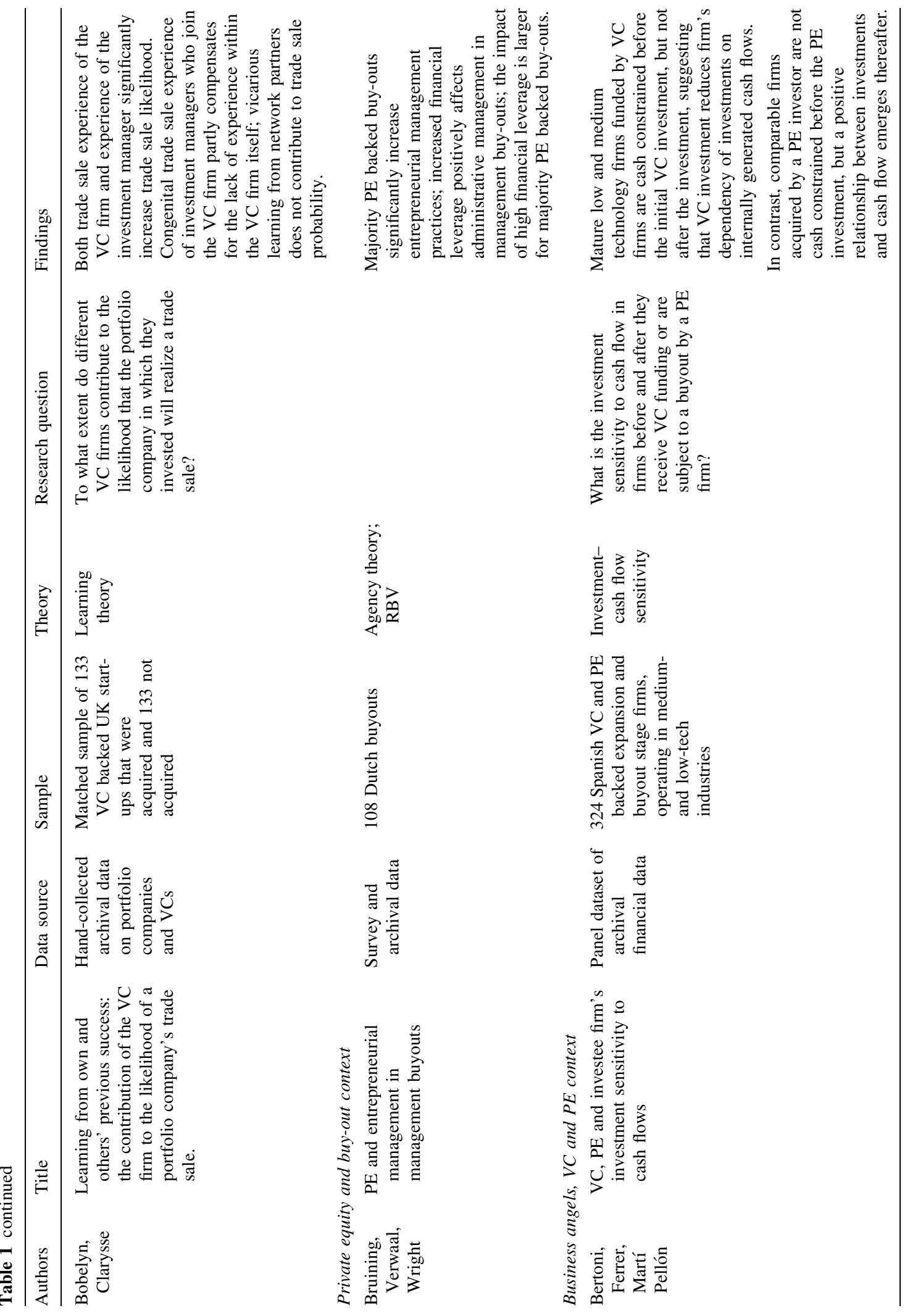


This pressure makes them push their portfolio companies harder to generate early sales, thereby enabling investors to show higher performance to outsiders. This short-term sales growth does not translate into a long term advantage for their portfolio companies, however. In a similar vein, Devigne and colleagues (2012) add to the emerging literature on cross-border $\mathrm{VC}$ by showing that the geographic origin of $\mathrm{VC}$ investors matters. In the short run, domestic VCs are more beneficial for portfolio company growth, as they have a deeper understanding of the local environment, but in the long run crossborder VC investors, providing access to and legitimacy in foreign markets, are more beneficial. Portfolio companies with syndicates comprising both domestic and cross-border investors outperform other companies, as they have access to both local and cross-border resources. Both studies further suggest that life cycle dynamics are important, and call for more attention to a dynamic view of VC/PE effects which may be remarkably different.

Bobelyn et al. (2012) show that VC investors learn from their experience. VC investment firms with more trade sale experience and with highly experienced investment managers increase the likelihood of their portfolio companies exiting through a trade sale. Congenital trade sale experience of investment managers who join the fund partly compensates for the lack of experience within the fund itself, but vicarious learning from network partners does not contribute to trade sale probability.

Bertoni and colleagues (2012a, b) focus on a largely neglected but highly important aspect of VC investing, namely, whether low and medium-tech VC backed companies have lower finance constraints after investment. They show that expansion-stage VC investors mainly invest in cash constrained companies, but firms that were acquired by a PE investor did not show investment-cash flow sensitivity before investment, suggesting that cash constraints are not motives for seeking PE investment in contrast to VC investment. After the investment, cash constraints in VC-backed firms disappear, while PE-backed firms seem to become more cash constrained. This suggests that the investment selection and management process of mature VC investors and PE investors is markedly different. Insights generated within the VC context cannot be fully transferred to the PE context.

In a study investigating the post-buy-out process, Bruining and colleagues (2012) show that buy-outs are 
not only efficiency driven. On the contrary, PE backed buy-outs significantly increase entrepreneurial management practices. Notwithstanding, increased financial leverage positively affects efficiency-induced administrative management in management buy-outs; the impact of high financial leverage is larger for majority PE backed buy-outs.

In a final study comprising both $\mathrm{VC}$ and business angel (BA) investments, the darker sides of the investor-entrepreneur relationship are explored. Collewaert and Fassin (2012), based upon U.S. and Belgian case studies, suggest that perceived unethical behaviour among venture partners triggers conflicts between them through increased fault attribution or blaming. Perceived unethical behaviour also affects partners' choice of conflict management strategy, thereby increasing the likelihood of conflicts escalating or having a negative outcome, including failure or involuntary exit of either entrepreneur or investor.

\section{An agenda for further research}

We envision an agenda for further research that recognizes the heterogeneity of $\mathrm{VC} / \mathrm{PE}$ equity types as well as the heterogeneity of contexts in which they invest. First, we propose that research on investor heterogeneity should more carefully consider the sources of heterogeneity within a VC/PE firm. Figure 1 presents how an investment firm may consist of different investment funds which, in turn, invest in different portfolio companies. Investor heterogeneity may hence originate at the firm, the fund and the investment portfolio level.

Second, we argue that, hitherto, research in entrepreneurial finance has not addressed sufficiently the heterogeneity of context in particular (Zahra and Wright 2011). Figure 2 shows how VC/ $\mathrm{PE}$ firms interact with the entrepreneurial team and the deal within a specific institutional and legal context. The effectiveness of investors' investment and involvement strategies is likely to be impacted by deal and team characteristics, and will depend on the institutional and legal context in which the investment takes place. Table 2 summarizes the interactions between the heterogeneity of investor type and context. We expand on these topics below.

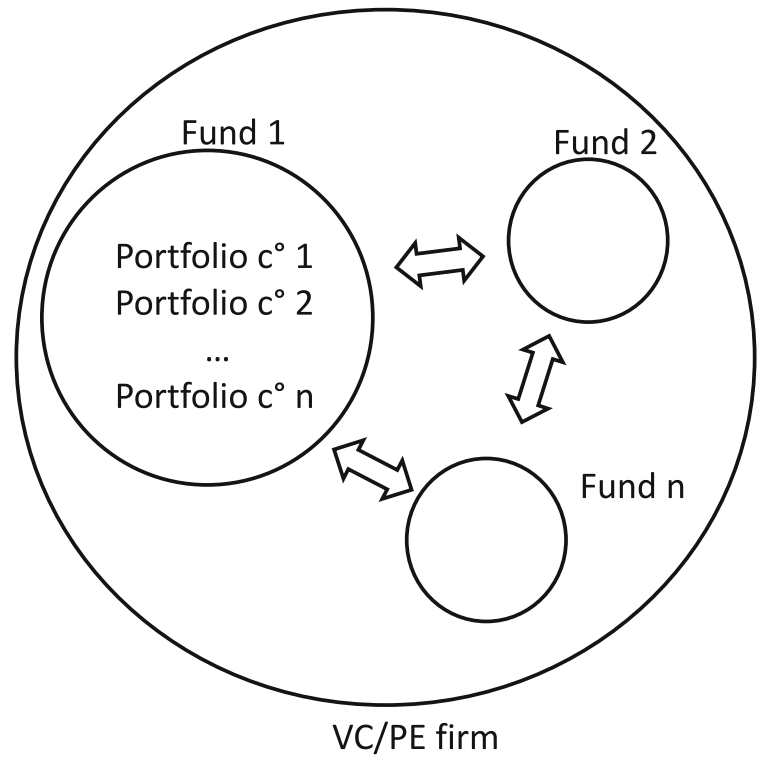

Fig. 1 Hierarchies within a venture capital or private equity firm

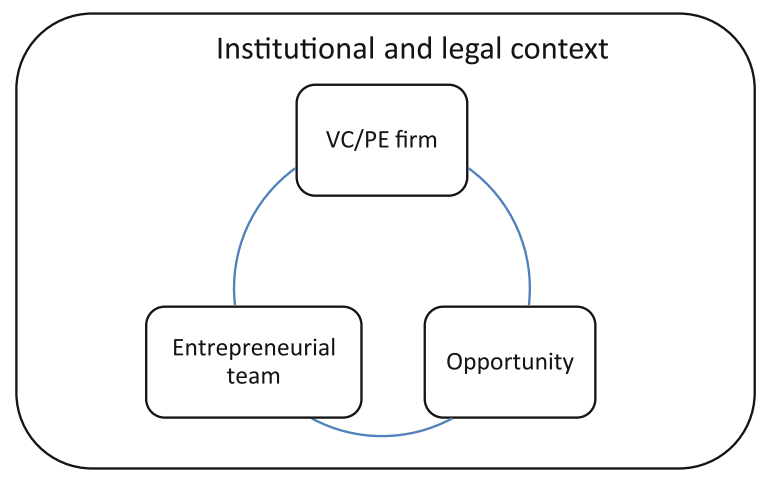

Fig. 2 Interactions between a venture capital/ private equity (VC/PE) firm, the entrepreneurial team, the deal and the context

\section{Investor characteristics}

Research on the impact of investor characteristics on their investment behavior is rapidly growing. Our current understanding of investor heterogeneity is very scattered, while the VC and PE investment nexus is complex. When considering business angel heterogeneity, the individual investors' human, social and financial capital and their psychological profile including their motivation lead to an idiosyncratic knowledge and experience base that impacts their investment process. The situation becomes more complex when deals are syndicated between business 


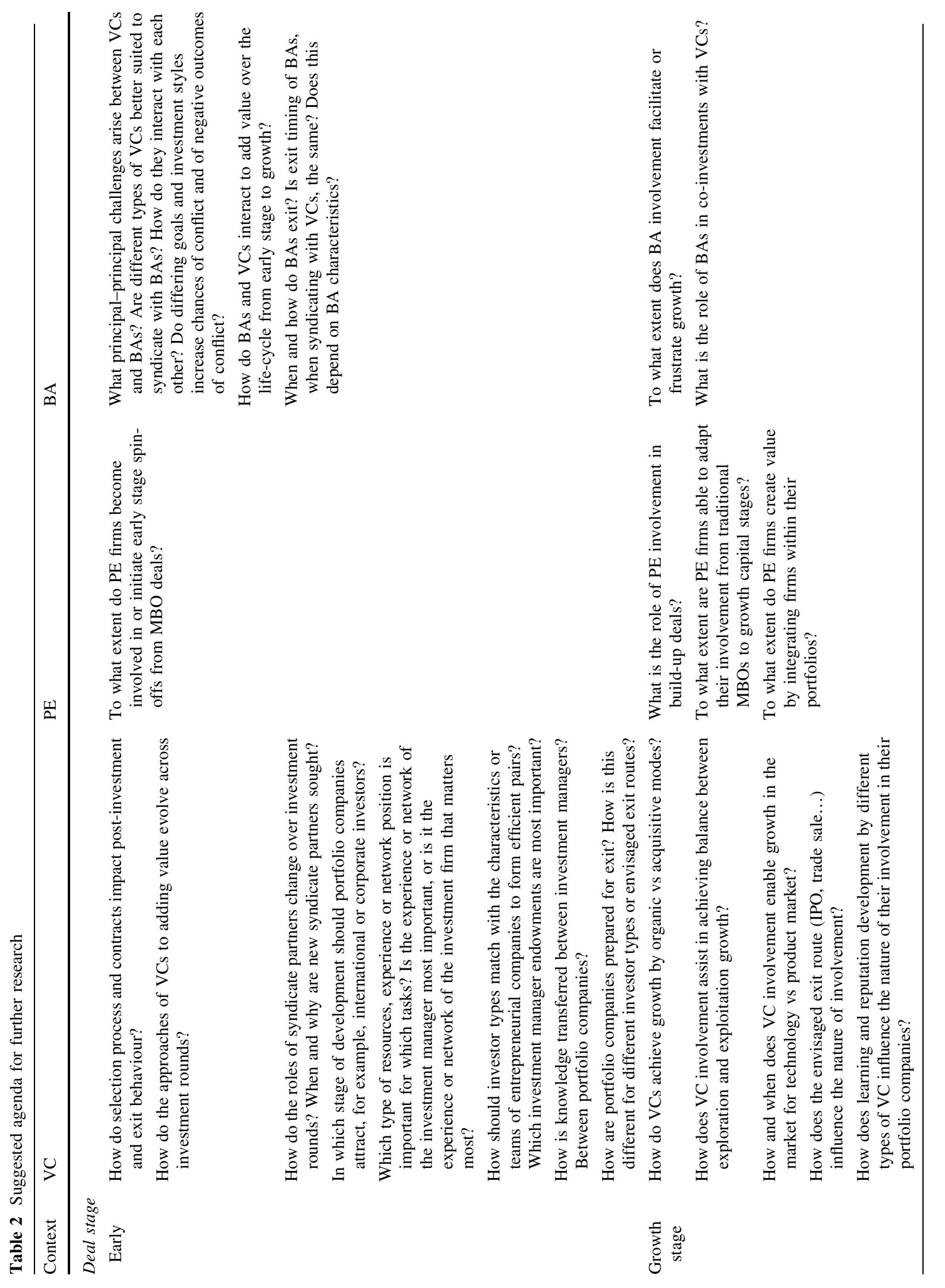




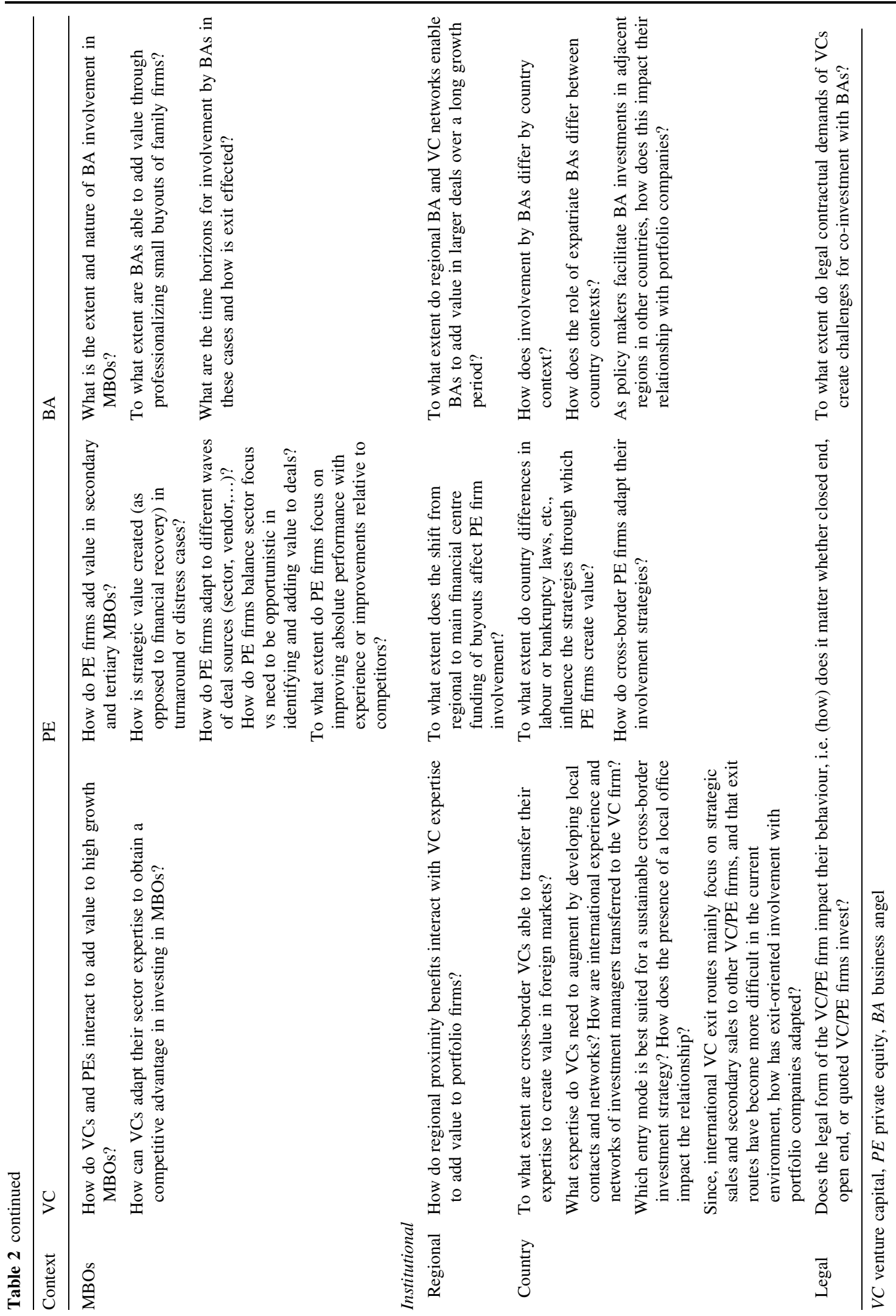


angels, calling for consideration of the interactions between investors with different characteristics. Complexity and heterogeneity further increase when different types of investors, including business angels, $\mathrm{VC}$ and PE investors, co-invest.

The situation of a $\mathrm{VC}$ or PE firm investing in an entrepreneurial company is more complex, however. Salient sources of heterogeneity reside at the investment firm level, at the fund level and at the level of their portfolio companies, calling for a hierarchical approach to investor heterogeneity. First, investment firms may differ in their legal form. Most VC and PE research has focused upon private independent firms managing closed ended funds. Yet, globally other legal forms exist. These forms include private open ended firms, firms that are listed on stock markets, and VC/PE firms that are subsidiaries of financial institutions and corporations. Comparative analysis of the different investment behaviours of these different types of legal forms is needed. These different legal forms may involve different investment objectives and time-scales, as well as differences in the expertise of executives and their incentives. For example, listed $\mathrm{VC} / \mathrm{PE}$ funds may be less constrained than closed end funds to generate returns to investors within a typical 10 -year period but on the other hand they may be constrained by the need to satisfy the demands of stock market analysts and the need to maintain quarterly earnings. Further research is needed to compare the risk-return behavior of these different firms and what this means for the relationships with portfolio firms.

$\mathrm{VC}$ and PE firms may also differ in their dominant shareholder or, in the realm of independent firms managing closed end funds, in their most important limited partners or LPs (Mayer et al. 2005). While independent investment firms typically raise funds from a wide variety of limited partners, captive firms receive all (or most) of the money to be invested from a parent company such as a corporate, a financial institution or a government-related organization. Differences in dominant shareholder may result in different investment objectives, compensation schemes for investment managers (and ensuing differences in investment managers characteristics and professionalism), or investment horizons. For example, public sector funds may place greater emphasis on social returns, and captive funds may have objectives at least partly to do with being a conduit for attracting new long-term customers for parent banks or new products for parent corporations.

Other investment firm characteristics that have been investigated in the literature are their experienceoften measured by age, the size of the pool of funds managed, the number of funds raised, the number of (successful) investments in general, in a specific industry or in a specific geographic area-their reputation or their network position (reflecting differences in syndicate patterns and partners). We call for more fine-grained studies on how experience and reputation can be disentangled, and how these important qualitative investor characteristics impact their selection, monitoring, value added and exit behavior. Further, dynamic studies could shed light on how reputation or network positions originate and change over time, with process studies being potentially fruitful in this area. As another example, at the growth stage learning and reputation development by different types of VC may influence the nature of their involvement in their portfolio companies. At present, we know little about these differences. As suggested at the outset, within each category of investor there is a further heterogeneity that has yet to be fully explored in terms of relationships with portfolio companies. For example, at the early stage, different types of $\mathrm{VC}$ firms may bring different sets of expertise that match with the expertise of entrepreneurs. In order to better understand the way in which value is created through VC relationships with portfolio firms we need to know more about which types of resources, experience or network position that a VC can bring are important for which tasks involved in the development of a venture. A particular issue relates to the potential difference in this regard between the experience or network of the investment manager or the experience or network of the VC/PE firm.

A second level of investor heterogeneity resides in the legal entity from which the investment takes place. Investments can be done in an investment fund (managed by an investment firm), or directly from the balance sheet managed by the parent. The latter situation often, but not always, occurs in captive investment firms, while the former typically occurs in independent investment firms. Mixed forms are also possible, with investment firms both managing investment funds and investing from their own balance sheet. These differences may, again, lead to differences in investment behavior, risk profile and outcomes. 
A third level of heterogeneity is the portfolio of investee companies. A highly concentrated portfolio implies a more concentrated risk in a specific industry or geographic region, but leads to a stronger knowledge base within the investment firm, which may be beneficial for value adding activities. Gaining a deeper understanding of this risk/return trade-off, and the underlying mechanisms driving differences in risk and return, is highly important. A neglected area of research in this respect is how investment managers learn from their portfolio companies and how they transfer this knowledge to other investee companies and to other investment managers.

More specifically, while PE firms are typically thought of as investing in later stage buyout deals, their moves to an industry or sector focus may mean that they may also become involved in early stage and growth deals. This may especially be the case given the challenges in generating returns from efficiency gains in buyout type investments. At present, the link between PE firms and the mix of investment stage(s) they invest in has not attracted attention. To what extent do PE firms have the mix of skills to enable them to grow as well as restructure portfolio companies? To what extent do PE firms need to syndicate with VC firms to access the skills they need to facilitate growth? In the post financial crisis environment, these are important challenges for PE investors given the difficulties in accessing significant amounts of debt that would enable them to achieve gains through leverage (Wright et al. 2010).

Aforementioned examples are but a few of the questions that could be addressed with respect to investment firm heterogeneity. While the different levels of heterogeneity have been addressed separately in previous research, studies that explicitly take into account the multiple levels of heterogeneity are lacking. Further investigating the interaction between the levels may be a fruitful area for further research.

\section{Deal context}

The relationship between investor and investee is not only shaped by investor characteristics, but also by the deal context, including the opportunity, the entrepreneurial team and the wider context in which the investment takes place. With respect to deal context, we suggest that while there has been a dichotomy in the literature between $\mathrm{VC}$ and buyout stages, there has been insufficient attention to an examination of the early and growth/later stage VC investments. Further research is warranted that examines these stages. For example, which types of investors are best suited to develop a specific type of portfolio company, or opportunities developed by entrepreneurial teams with an idiosyncratic mix of resources, knowledge and experience?

VC typically involves multiple rounds of investment. Although there are comparisons of VC involvement of different stages of investment, we know little about how VC involvement changes across these investment rounds. How do approaches to value creation differ across rounds? How does the role of syndicate partners in enabling the development of the venture changes across investment rounds? How and when does the process occur through which different types of investors such as corporate or international investors occur? The questions of what challenges arise and how they are overcome in the process of moving from one round to the next also arise and warrant further scrutiny. These differences may also be linked to and influence the eventual exit route selected.

After IPO exit, VC investors sometimes stay as partial owners and/or board members. Our current understanding of how boards of VC-backed firms change after IPO is limited. For example, what determines whether VC managers stay as a board member? And what effect does that have on post-IPO performance?

Although for expositional reasons Table 2 takes $\mathrm{VC} / \mathrm{PE} / \mathrm{BA}$ as distinct categories, research has largely neglected the interactions between these types of investors. As ventures develop through their life cycle questions arise concerning whether one type of investor exits fully as the new one enters or whether earlier stage investors remain in place. For example, to what extent do BAs remain in place when formal VCs enter the deal and to what extent do these investors remain in place when PE firms enter? This leads to consideration of the associated rationale for and challenges involved in retaining earlier stage investors with potentially different skills and objectives. From the perspective of the main focus of this special issue, for example, to what extent do earlier stage investors continue to add value to or frustrate the development of ventures? Are BA investors retained because they 
continue to bring important market reputation? Are VC investors retained because they have specialist sector expertise not possessed by a more financially oriented PE firm? Do earlier stage investors continue to play a role on boards or become involved in facilitating the development of more appropriate boards for the next life cycle phase? More generally, conceptual issues are raised concerning the nature of principal-principal problems between BAs, VCs and PEs and how these are resolved.

In the entrepreneurial growth literature it is beginning to be recognized that it is important to gain more fine-grained understanding about the nature of growth, not just the extent of growth (McKelvie and Wiklund 2010; Clarysse et al. 2011). Similarly, there is a need for greater understanding of the nature of the contribution of VCs at the growth stage. At its simplest, such analysis might examine the role of $\mathrm{VCs}$ in promoting organic versus acquisitive growth or a mix of the two. But it is coming to be recognized that growth may also be achieved through explorative activities that create new products and markets as well as through the exploitation of these innovations. As ventures develop, particularly high tech cases, there may be a shift from exploration to exploitation. This shift may not be a wholesale move as it may be important to maintain explorative activities that will help generate future exploitations. Relatedly, growth may be achieved in the technology market or the product market or both. These different growth modes may call for different nature of involvement by VCs as the firm develops. They may also require different types of VCs with different skills to be introduced. Although Clarysse et al. (2011) have tentatively identified the roles of different types of VCs able to bring differing skills and amounts of funding according to the market environmental context of the venture, research in this area is at a relatively early stage. Devoting further attention to this topic may be especially important in yielding insights into the processes by which VCs facilitate venture growth and why some VC backed ventures grow more than others. With respect to both VC firms and PE firms an unexplored issue concerns the extent to which growth is achieved and value created by integrating firms within their own portfolios.

With respect to buyout stage investments, most attention has traditionally focused upon PE firms. We now know a substantial amount about the influence of PE firms in value creation (Cumming et al. 2007; Wright et al. 2009). However, while we are beginning to gain insights into whether secondary and tertiary deals generate further value creation (Nikoskelainen and Wright 2007; Jelic and Wright 2011), understanding of how this is created is limited. To what extent are gains generated through further efficiency gains or growth? What challenges are posed in creating these gains in secondary and tertiary deals and how do they differ from value creation in primary deals? To what extent do secondary and tertiary deals involve the introduction of larger PE investors with international networks who can take firms to the next stage of growth?

Besides PE firms, both VCs and BAs may be involved in buyout deals, raising questions about what distinctive expertise they bring. For example, to what extent do BAs focus on funding buyouts of smaller family firms and divisions that would not be attractive to formal PE firms? This role may be an important one given that many PE firms have largely vacated the smaller end of the buyout market (CMBOR 2011). However, we have little evidence of the extent to which BAs invest in these kinds of deals, what the nature of their relationship is with investees and what their objectives are.

The economic environment, particularly the recent financial crisis, may also play an important role in the nature of involvement that is required of investors. For example, while recession may require rescue and restructuring of deals, there may still be growth opportunities. Further, the nature of restructuring that is undertaken may have adverse implications for the longer term growth of the company. Different types of investor may be better placed to provide different types of assistance in such cases. For example, distress and turnaround PE funds may approach buyouts in distress differently from more traditional PE investors. At present, we have little systematic evidence on the different nature of the involvement by these types of firms. Further, distress and turnaround funds may also have different business models regarding how they view the nature and timing of value creation, and this warrants further examination. Expectations about future economic development also influence the kind of deals that investors seek and the consequent nature of their relationships with portfolio companies. 


\section{Entrepreneurial team context}

Not only is the nature of the opportunity important in the investor-investee relationship, but also the entrepreneur or entrepreneurial team developing the opportunity. Little is known, however, on the importance of complementarity of skills and resources embedded in the entrepreneurial team and the investment firm. For example, while some complementarity in resources seems to be important for investors being able to add value, some overlap might be fruitful to enhance mutual understanding and hence learning. Further, while most research to date focused on how investees learn from investors, the latter may also learn from the former. Finally, while numerous papers have examined the replacement of entrepreneurs by their investors, little is known about how investors are instrumental in shaping the entrepreneurial teams. When do they add or replace new team members? And how instrumental are they in initiating the hiring of middle managers? Do they actively recycle managerial talent between portfolio companies? These questions, while important, have largely been neglected up to now.

\section{Institutional context}

The influence of institutional contexts can be considered at both between country and within-country regional levels. At the regional level, proximity benefits in terms of access to VC/PEs may be important in accessing funding and expertise that can, for example, help early stage ventures to grow and to enable buyouts of family firms and smaller divisions to be effected. However, there has been little systematic analysis of the extent to which there is reliance on local VC/PE firms versus the ability to attract investors from further afield. Where does the boundary lie between these two decisions and what influences it? For example, to what extent do intermediaries play a role in attracting VC/PE investors who are able to provide the requisite kind of involvement even though they are more distant? To what extent are proximity benefits for obtaining the best fit of investor more important for early, growth or buyout stage investments? To what extent are 'good' deals able to identify and attract VC/PE investors who can provide the relational investment they need from outside their local environment? This also raises a wider issue concerning the level of deal flow that is needed to maintain a vibrant local VC/PE environment.

Successful investment by BAs may require the ability to assemble regional syndicates of BAs who can provide both expertise and more significant sums of money to enable growth of early stage ventures that are unable or unwilling to attract formal VC.

With respect to between country level issues, there is a need to analyse to what extent the human and social capital of VC and PE firm executives is mobile across institutional boundaries (Meyer et al. 2009). Yet, foreign VC/PEs may need to access expertise and networks in the host country to supplement their own expertise. More research is needed on how foreign firms transfer and access expertise and how these feed through into the relationships with portfolio firms.

With different regulatory frameworks in different countries, notably differences in labour laws, PE firms may need to adapt their approaches to restructuring buyout deals. Alternatively, they may select different types of deals.

Investor protection rights and enforcement thereof largely differ between different contracts and institutional contexts. This impacts investment strategies, the nature of the contracts and therefore also the relationship between investors and portfolio companies. While research has been initiated in this area, more insights are needed.

\section{Future industry outlook}

This special issue has aimed to reassess the relationships between PE investors and their portfolio companies in the light of the need for VC/PE firms to adapt their strategies for value creation in the light of the recent financial crisis. Since the onset of the financial crisis in 2008 there has been debate about the recovery of the global economy. During this period, there was some modest recovery in VC and PE activity but this remained well below earlier peaks, especially for early stage VC (EVCA 2011). Economic recovery has generally been slow and in 2011 further concerns were raised about the impact of highly indebted nations on worldwide growth and economic stability. As such, the future trajectory of VC and PE market development remains uncertain and along with it expected developments in the relationships between $\mathrm{VC} / \mathrm{PE}$ firms and their portfolio companies. 
Table 3 Future options for venture capital and private equity

\begin{tabular}{lll}
\hline Activity & Returns & \\
\cline { 2 - 3 } & Lower & Higher \\
\hline Lower & Quadrant 1 & Quadrant 4 \\
& Lack of LP interest & Lack of primary deal availability \\
& Risk aversion by VC/PEs & Development of value adding skills \& active \\
& Lack of deal availability & board involvement \\
& Lack of skills to add value & Build-up deals \\
& VC/PE firm exits & Exits of under-performing VC/PE firms \\
& Quadrant 2 & Quadrant 3 \\
& Pressure to do deals & Continued LP interest \\
& Lack of VC/PE sophistication & New deal, funding, VC/PE firm \& exit types \\
& Lack of skills to add value & Ability to create value from secondaries, \\
& Little VC/PE firm exit & tertiaries... \\
& & Development of value adding skills \\
& & Debt availability \\
\hline
\end{tabular}

Four potential future development options for VC and PE can be categorized in terms of combinations of lower versus higher deal activity and lower versus higher returns (Table 3). If macro-economic activity continues to stabilize, quadrant 1 in Table 3 involving low activity and low returns seems unlikely if institutional investors' interest returns to the market, VC/PE firms are able to raise new funds, and confidence returns regarding valuations and exit markets. But if structural problems in the economy are not resolved, significant market resurgence would likely be delayed. Lack of LP interest and lack of deals at attractive prices would cause many VC and PE firms to exit. If potential deals are only available at high entry prices, and access to debt finance remains limited in an economy that is not growing, it may be extremely difficult to generate significant returns.

Increased activity coupled with low returns, as in quadrant 2, may arise if the economy improves but VC and PE firms fail to develop their value adding skills. Coming under pressure to invest the funds they have raised, they might target poor deals, leading to poor outcomes. A return to higher levels of deal activity and higher returns would seem to require several developments to come together as shown in quadrant 3 . Besides developing $\mathrm{VC}$ and $\mathrm{PE}$ firm and investment managers' skills, there would need to be a resurgence of debt funding, the identification of new deal types and means found to add value to secondary and tertiary deals. Finally, quadrant 4 envisages a more modest level of deal activity but the generation of higher returns as continuing $\mathrm{VC}$ and $\mathrm{PE}$ firms develop differentiated value adding skills and focus on buildup and secondary buyouts in an environment of restricted primary deal availability. More sophisticated VC and PE firms are expected to drive out underperforming peers, leading to a shake-out in the industry. At the time of writing (Fall 2011) it is unclear which option seems most likely to unfold. However, whichever scenarios emerge, they are likely to emphasize the opportunities to examine the influence of varying economic contexts on relationships between PE investors and their portfolio companies.

\section{References}

Baum, J. A. C., \& Silverman, B. S. (2004). Picking winners or building them? Alliance, intellectual, and human capital as selection criteria in venture financing and performance of biotechnology startups. Journal of Business Venturing, 19(3), 411-436.

Bertoni, F., Colombo, M., \& Grilli, L. (2012a). Venture capital investor type and the growth mode of new technology based firms. Small Business Economics. doi:10.1007/ s11187-011-9385-9.

Bertoni, F., Ferrer, M. A., \& Martí Pellón, J. (2012b). Venture capital, private equity and investee firm's investment sensitivity to cash flows. Small Business Economics.

Bobelyn, A., Clarysse, B., \& I. del Palacio Aguirre (2012). Learning from own and others' previous experience: The contribution of the venture capital firm to the likelihood of a portfolio company's trade sale. Small Business Economics. doi:10.1007/s11187-011-9381-0. 
Bottazzi, L., \& Da Rin, M. (2002). Venture capital in Europe and the financing of innovative companies. Economic Policy, 17(34), 229-270.

Bruining, H., Verwaal, E., \& Wright, M. (2012). Private equity and entrepreneurial management in management buyouts. Small Business Economics. doi:10.1007/s11187-011-9386-8

Clarysse, B., Bruneel, J., \& Wright, M. (2011). Explaining growth paths of young technology-based firms: Structuring resource portfolios in different competitive environments. Strategic Entrepreneurship Journal, 5(2), 137-157.

CMBOR. (2011). Management buyouts: Quarterly review from CMBOR. Nottingham: Centre for Management Buyout Research (CMBOR), Spring.

Collewaert, V., \& Fassin, Y. (2012). Conflicts between entrepreneurs and investors: The impact of perceived unethical behavior. Small Business Economics. doi:10.1007/s11187011-9379-7.

Colombo, M. G., \& Grilli, L. (2010). On growth drivers of hightech start-ups: Exploring the role of founders' human capital and venture capital. Journal of Business Venturing, 25(6), 610-626.

Cumming, D., Siegel, D. S., \& Wright, M. (2007). Private equity, leveraged buyouts and governance. Journal of Corporate Finance, 13, 439-460.

Devigne, D., Vanacker, T., Manigart, S. \& Paeleman, I. (2012). The role of domestic and cross-border venture capital investors in the growth of portfolio companies. Small Business Economics. doi:10.1007/s11187-011-9383-y.

EVCA. (2011). European venture capital and private equity. Brussels: EVCA.

Filatotchev, I., Wright, M., \& Arberk, M. (2006). Venture capitalists, syndication and governance in initial public offerings. Small Business Economics, 26(4), 337-350.

Fitza, M., Matusik, S. F., \& Mosakowski, E. (2009). Do VCs matter? The importance of owners on performance variance in start-up firms. Strategic Management Journal, 30, 387-404.

Gompers, P. A. (1996). Grandstanding in the venture capital industry. Journal of Financial Economics, 42(1), 133-156.

Gompers, P. A., Kovner, A., Lerner, J., \& Scharfstein, D. (2008). Venture capital investment cycles: The impact of public markets. Journal of Financial Economics, 87(1), 1-23.

Hellmann, T., Lindsey, L., \& Puri, M. (2008). Building relationships early: Banks in venture capital. Review of Financial Studies, 21(2), 513-541.

Hirsch, J., \& Walz, U. (2012). Why do contracts differ between venture capital types? Small Business Economics. doi: 10.1007/s11187-011-9388-6.

Janney, J. J., \& Folta, T. B. (2006). Moderating effects of investor experience on the signalling value of private equity placements. Journal of Business Venturing, 21(1), 27-44.

Jelic, R., \& Wright, M. (2011). Exits, performance, and late stage capital: The case of UK management buy-outs. European Financial Management.

Kelly, P. (2007). Business angel research: The road travelled and the journey ahead. In H. Landstrom (Ed.), Handbook of research on venture capital. Cheltenham: Edward Elgar.
Knockaert, M., \& Vanacker, T. (2012). The association between venture capitalists' selection and value adding behavior: Evidence from early stage high tech venture capitalists. Small Business Economics. doi:10.1007/s11187-011-9378-8.

Lockett, A., Wright, M., Burrows, A., Scholes, L., \& Paton, D. (2008). The export intensity of venture capital backed companies. Small Business Economics, 31(1), 39-58.

Mäkelä, M. M., \& Maula, M. V. J. (2006). Interorganizational commitment in syndicated cross-border venture capital investments. Entrepreneurship Theory and Practice, 30(2), 273-298.

Mäkelä, M. M., \& Maula, M. V. J. (2008). Attracting crossborder venture capital: the role of a local investor. Entrepreneurship and Regional Development, 20(3), 237-257.

Manigart, S., \& Wright, M. (2012). Venture capital investors and portfolio firms. Foundation and trends in entrepreneurship. Boston: Now Publishers.

Mayer, S., Schoors, K., \& Yafeh, Y. (2005). Sources of funds and investment activities of venture capital funds: Evidence from Germany, Israel, Japan and the UK. Journal of Corporate Finance, 11, 586-608.

McKelvie, A., \& Wiklund, J. (2010). Advancing firm growth research: A focus on growth mode instead of growth rate. Entrepreneurship Theory and Practice, 34, 261-288.

Meyer, K., Wright, M., \& Pruthi, S. (2009). Managing knowledge in foreign entry strategies: A resource-based analysis. Strategic Management Journal, 30(5), 557-574.

Nikoskelainen, E., \& Wright, M. (2007). The impact of corporate governance mechanisms on value increase in leveraged buyouts. Journal of Corporate Finance, 13(4), 511-537.

Sapienza, H. J., Manigart, S., \& Vermeir, W. (1996). Venture capitalist governance and value added in four countries. Journal of Business Venturing, 11(6), 439-469.

Shepherd, D. A. (1999). Venture capitalists' assessment of new venture survival. Management Science, 45(5), 624-634.

Timmons, J. A., \& Bygrave, W. D. (1986). Venture capital's role in financing innovation for economic growth. Journal of Business Venturing, 1(2), 161-176.

Vanacker, T., \& Manigart, S. (2010). Incremental financing decisions in high growth companies: Pecking order and debt capacity considerations. Small Business Economics, 35(1), 53-69.

Wright, M., Amess, K., Weir, C., \& Girma, S. (2009). Private equity and corporate governance: Retrospect and prospect. Corporate Governance: An International Review, 17(3), 253-375.

Wright, M., Jackson, A., \& Frobisher, S. (2010). Private equity in the UK: Building the new future. Journal of Applied Corporate Finance, 22(4), 86-95.

Zahra, S. A., \& Wright, M. (2011). Entrepreneurship's next act. Academy of Management Perspectives, 25(4).

Zahra, S. A., Neubaum, D. O., \& Nandi, L. (2007). The effect of ownership and governance on SME's international knowledge-based resources. Small Business Economics, 29(3), 309-327. 